\title{
Enhancing oilseeds cold pressing techniques based on HAZOP analysis for prickly pear seeds, Opuntia ficus-indica (L.) Mill.
}

\author{
Kamilia Alhamdaoui ${ }^{1, \bowtie}$, Chouaib Benqlilou ${ }^{2}$, Haiat Essalmani ${ }^{1}$ \\ ${ }^{1}$ Department of Biotechnology, University Abdel Malek Essaadi Tangier, Faculty of Sciences and Techniques of Tangier, \\ Ancienne Route de l'Aéroport, Km 10, Ziaten. BP416. Tangier, Morocco \\ ${ }^{2}$ Department of Industrial Process Engineering,Energy Systems and Thermal Processes, Rabat School of Mines, Av. Ahmed \\ Cherkaoui, BP753, Agdal, Rabat, Morocco
}

$\triangle$ Corresponding author: alhamdaoui.kamilia@gmail.com

\section{Article info}

\section{Article history:}

Received: $12^{\text {th }}$ January 2021

Accepted: $18^{\text {th }}$ March 2021

\section{Keywords:}

Cold press specification

Hardness

HAZOP analysis

Oilseed

Tocopherol

Yield

\begin{abstract}
The main goal of the present study was to determine optimal conditions for the extraction of oil with high added value by cold pressing technique. Namely the feeding conditions of the Opuntia ficus-indica (L.) Mill. (OFI) seeds, as well as the definition of the manipulable variables of the Kern-Kraft 20 press were specified. These specifications combine HAZOP (Hazard and Operability) analysis and experience plan to find out correlation between yield and oil quality with the pressure, temperature, nozzle diameter, residence time, pressing speed while considering high hardness level of the seed under study. The seed oil extracted according to the proposed approach was highly unsaturated where linoleic acid is the main fatty acids (60.42\% of total fatty acids), followed by oleic acid (21.65\%), palmitic acid (12.24 $\%)$, and stearic acid (3.88\%), respectively. Furthermore, it is worth mentioning that beta-sitosterol and gamma-tocopherol were the principal components of sterols and tocopherols representing $67.56 \%$ of total sterols and $330 \mathrm{mg} \cdot \mathrm{kg}^{-1}$ of total tocopherols. The proposed approach applied to prickly pear seeds had preserved the tocopherol fraction (796.70 mg. $\mathrm{kg}^{-1}$ of total tocopherols) about two times more than other coldpressed seed oils approaches. Based on trial-and-error conditions, no additional operating problem even has been reported with a seed of high level of hardness. Seed should be introduced with a humidity level of $10 \%$ without grinding. Moreover, no heating should be supplied and an optimal pressing speed of 30 and a nozzle diameter of $15 \mathrm{~mm}$.
\end{abstract}

(C) University of SS. Cyril and Methodius in Trnava

\section{Introduction}

The oilseed industry allows the production of oil as a high value-added product with specified quality a that meets the requirements of downstream health industries, namely cosmetics, pharmaceuticals and nutraceuticals. In recent years, a growing demand has been observed which consequently promotes extractive techniques under the concept of biorefining (Laurent et al. 2011). These industries extract vegetable oils through various techniques, the most commonly cost-efficient are based on solvent extraction and cold pressing. Although the latter has a reduced yield compared to the former one, it is more appropriate for health-related purposes since it is solvent free and preserves oil quality in terms of fatty acids and the levels of bioactive elements such as: tocopherol, squalen, and sterol (Koski et al. 2002; Bail et al. 2008).

However, during the cold pressing method if the 
press set points conditions are not well specified and seed properties (such as hardness, oil content, moisture content, granulometry, etc.) are not taken into account, serious problems could emerge in terms of yield. For instance, significant oil loss in the cake, quality deterioration, productivity loss, production cost could be caused. Other problems such as operability risks could occur, such as operating loss, mechanical equipment failure and occupational risks.

In the literature there are some guidelines that indicate the appropriate conditions for oil seed extraction (Schaufler and Schaufler et al. 2013). Nevertheless, less research has been done on seed hardness, whose approach has been mainly based on trial and error procedure. In order to achieve adequate cold pressing and produce high-quality oil without operating issues, a cold pressing method is carried out on prickly pear (Opuntia ficus-indica (L.) Mill.) seeds, using HAZOP analysis to study the operational and hazardous conditions related to the cold pressing process. Prickly pear seeds are considered a raw-material for cosmetic oil production. They contain valuable oil. However, they present a relatively high level of hardness. Consequently, these seeds are chosen as reference to study seeds leading to low yield as well as operability risks.

The adopted approach combines HAZOP analysis and experience plan, so it is possible to specify the optimal conditions for oilseed extraction based on cold pressing. Indeed, HAZOP as the method of qualitative approach allows to identify and record hazards based on formalized and systematic thinking through a multidisciplinary team examining potential intent deviations (Kletz 1999; Reniers et al. 2005). HAZOP significantly reduces the number of experiments to carry out in order to find out the best correlation between yield and quality of the extracted oil and the manipulated variables of the cold pressing, namely pressure, temperature, nozzle diameter, residence time, pressing speed.

To assess the oil quality, the Gas chromatography (GC) and High-performance liquid chromatography (HPLC) were performed to determine the composition of fatty acids, sterols and tocopherols, respectively.

\section{Experimental}

\section{Oil extraction by cold pressing method}

Seeds of the prickly pear (Opuntia ficus-indica (L.) Mill. (OFI) with high hardness are the most used seeds for oil extraction in Morocco. Samples from the Ait Baamrane region in southern Morocco were obtained and their properties were studied (weight, humidity, grain size, and others). Seed oil was extracted by the cold pressing method (Fig. 1) at a laboratory scale. It is a technological mechanical process of extracting oil from the seeds by applying the required pressure according to seed characteristics. The cold pressing was performed using a screw press Kern \& Kraft Press (KK-20, Germany) with capacity of $20 \mathrm{~kg} \cdot \mathrm{h}^{-1}$ of seed, equipped with engine of $2.0 \mathrm{~kW}$, a speed variator, various nozzle diameter as well as a heating system for temperature control.

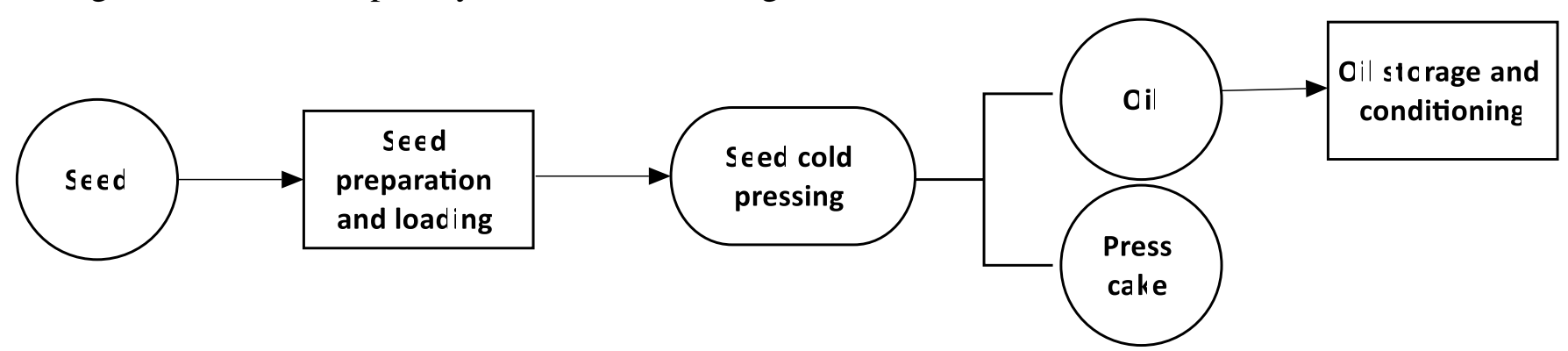

Fig. 1. Scheme of the cold pressing extraction of oil from OFI seeds.

\section{Oil yield}

The seed oil content was determined using the Soxhlet method according to ISO 659 (1998). Seeds were grinded using a blender into a fine and homogeneous powder. Twenty grams of powder was subjected to extraction with hexane $(100 \mathrm{~mL})$ at 40 $60{ }^{\circ} \mathrm{C}$ in the Soxhlet extractor. After evaporation of 
the solvent under reduced pressure, using a rotary evaporator at $40-60{ }^{\circ} \mathrm{C}$, the oil content was calculated and expressed as a percentage of seed dry matter according to the following formula (Eq. 1):

$Y(\%)=100 \cdot \frac{W e}{W t}$

$\mathrm{W}_{\mathrm{e}}$ : weight of fat extracted $(\mathrm{g})$

$\mathrm{W}_{\mathrm{t}}$ : weight of test sample (seed powder) $(\mathrm{g})$

After determining seed oil content, the total yield extracted by cold pressing was calculated according to the formula (Eq. 2):

Yield $=100 \cdot \frac{\text { Oil yield extracted by cold pressing }}{\text { Seedoil content }}$

\section{Fatty acid composition}

The fatty acid profile was determined using method ISO 5508 (1990). Before the analysis, fatty acids were converted to fatty acid methyl esters by shaking a solution of $60 \mathrm{mg}$ of oil and $3 \mathrm{~mL}$ of hexane with $0.3 \mathrm{~mL}$ of $2 \mathrm{~N}$ methanolic potassium hydroxide. Fatty acids were analyzed by gas chromatography GC (Agilent G-97-04A) equipped with flame ionization detector (FID) and a columnar capillary filled with a stationary phase (70 \% cyanopropyl polysilphenylene, length: $60 \mathrm{~m}$, internal diameter: $0.25 \mathrm{~mm}$, film thickness: $0.250 \mu \mathrm{m}$ ). The carrier gas was hydrogen, and the total gas flow rate was 1.6 $\mathrm{mL} \cdot \mathrm{min}^{-1}$. The initial column temperature and the final temperature were $140{ }^{\circ} \mathrm{C}$ and $200{ }^{\circ} \mathrm{C}$, respectively. The injector and detector temperature were $280{ }^{\circ} \mathrm{C}$. Fatty acids were identified by comparison of their retention times with standard mixtures.

\section{Sterols composition}

The sterol fraction was determined using the method ISO 6799 (1991) by GC (Agilent 19091J-436 HP-5, 5\%-phenylmethylsiloxane). After the extraction and isolation of the unsaponifiable, the gas chromatographic analyzes were carried out using a column (length: $60 \mathrm{~m}$, nominal diameter: $250 \mu \mathrm{m}$, nominal film thickness $0.25 \mu \mathrm{m}$ ) with a helium carrier gas (flow $1.5 \mathrm{~mL}_{\mathrm{min}}^{-1}$ ). The column temperature was isothermal at $270{ }^{\circ} \mathrm{C}$, injector and
MS detector temperature were $300{ }^{\circ} \mathrm{C}$. The sterols quantification was based on the comparison of the spectra with those in the literature.

\section{Tocopherols composition}

Tocopherols were identified based on the international standard ISO 9936 (2006), using HPLC Shimadzu LC-10ad VP 230V CE normal phase Isooctane/Isopropanol (99: 1, v/v). Solution of $2 \mathrm{~g}$ of oil in $25 \mathrm{~mL}$ of isooctane (flow rate of $1.2 \mathrm{~mL} . \mathrm{min}^{-}$ 1) was directly used for the HPLC, using octadecylsilane silica $\left(\mathrm{C}_{18}\right)$ column as stationary phase (length : $250 \mathrm{~mm}$, internal diameter : $4.6 \mathrm{~mm}$, thickness of the film : $5 \mu \mathrm{m}$ ) with the fluorometer detector set at $292 \mathrm{~nm}$, to ensure a high selectivity and to differentiate many forms of isomers antioxidants. Tocopherols were identified by comparing their retention times with those of authentic standards.

\section{Quality indices (acidity, peroxide value)}

In order to check the quality and appropriate conservation of the obtained seed oil, the acidity (A) (expressed as percentage of oleic acid) and the peroxide value (PV) (expressed as milliequivalents of active oxygen per $\mathrm{kg}$ of oil) were measured.

Acidity (A) is the amount of free fatty acids expressed as a percentage of oleic acid. The acidity of the prickly pear seed oil was determined according to the method ISO 660 (1996). An amount of $10 \mathrm{~g}$ of prickly pear oil was added to $50 \mathrm{~mL}$ of neutralized ethanol/diethyl ether mixture (1: $1, \mathrm{v} / \mathrm{v})$ in the presence of phenolphthalein as indicator, then titrated with potassium hydroxide solution $\mathrm{NaOH}$ $(0.1 \mathrm{M})$.

Acidity was calculated as follows (Eq. 3):

$A(\%)=\frac{V \times C \times M}{10 \times m}$

$\mathrm{V}: \mathrm{NaOH}$ volume $(\mathrm{mL}) ; \mathrm{C}: \mathrm{NaOH}$ concentration $\left(\right.$ mol.L $\left.\mathrm{L}^{-1}\right) ; \mathrm{M}$ : Oleic acid molar mass $\left(282{\left.\mathrm{~g} . \mathrm{mol}^{-1}\right)}^{-1}\right.$ $\mathrm{m}$ : Oil mass in grams $(\mathrm{g})$.

Peroxide Value (PV) is defined as the number of mili-equivalents of oxygen per kilogram of fat. It is determined following the method ISO 3960 (1977). 
An amount of $5 \mathrm{~g}$ of prickly pear oil was added to 10 $\mathrm{mL}$ of chloroform, $15 \mathrm{~mL}$ of acetic acid, mixed all with $1 \mathrm{~mL}$ of saturated potassium iodide. The mixture was left in darkness, then $75 \mathrm{~mL}$ of distilled water was added. The mixture was titrated with sodium thiosulphate $(0.01 \mathrm{~N})$, using starch solution as indicator. The Peroxide value was calculated as follows (Eq. 4):

$$
P V\left(\mathrm{meqO}_{2} / \mathrm{kg}\right)=\frac{\left(V_{x}-V_{0}\right) \times N}{m} \times 1000
$$

$\mathrm{Vx}$ : Sodium thiosulfate volume $(\mathrm{mL})$ for the titration; V0: Sodium thiosulfate volume $(\mathrm{mL})$ for the blank; N: Sodium thiosulfate Normality; m: Oil mass in grams $(\mathrm{g})$.

\section{HAZOP method}

During the preliminary experiments, various incidents during the cold press oil extraction of prickly pear seeds were observed due to their high hardness. It caused serious problems in yield (significant oil loss in the cake, quality deterioration, etc.) and operability (operating loss, mechanical equipment failure, occupational risks). For this purpose, the HAZOP method was adopted to determine operational and risk conditions during start-up, steady-state operation, and press shut down. The system was subdivided mainly into three subsystems as shown in the Table 1 .

Table 1. The proposed nodes for HAZOP analysis application.

\begin{tabular}{ll}
\hline Sub system & Node \\
\hline $\begin{array}{l}\text { Raw material conditioning \& } \\
\text { feeding }\end{array}$ & $\begin{array}{l}\text { I: Seed supply conditions } \\
\text { and press loading }\end{array}$ \\
$\begin{array}{l}\text { Production (steady state } \\
\text { operation) }\end{array}$ & $\begin{array}{l}\text { II: Seed pressing for oil } \\
\text { extraction and cake } \\
\text { recovery purposes }\end{array}$ \\
$\begin{array}{l}\text { Conditioning and storage of the } \\
\text { obtained oil }\end{array}$ & $\begin{array}{l}\text { III: Conservation of the } \\
\text { extracted oil }\end{array}$ \\
\hline
\end{tabular}

In each node the process parameters were identified (Table 3) considering the experiment design of the in situ oil extraction, the feedback from oilseed industrial operators and the literature data. (Frạczek et al. 2005; Lacoste et al. 2005; Altuntaş and Y1ld1z
2007; Soetaredjo et al. 2008; Van Hoed et al. 2010; Matthäus and Özcan 2011; Nitièma-Yefanova et al. 2012; Chougui et al. 2013; Schaufler and Schaufler et al. 2013; Rabrenović et al. 2014; Fuentes-Bargues et al. 2016).

The study was performed following the steps of the HAZOP process (Fig. 2). Indeed, the process parameters associated with guidewords (Table 2) were depicted in order to unveil the most significant deviations that could involve risks or dangers in each subsystem. Eighteen significant deviations were generated (Table 3 ).

Table 2. Standard guidewords and their generic meanings.

\begin{tabular}{|c|c|}
\hline Guidewords & Interpretation \\
\hline No (not, none) & None of the design intent is achieved \\
\hline More (more of, higher) & Quantitative increase in a parameter \\
\hline Less (less of, lower) & Quantitative decrease in a parameter \\
\hline As well as (more than) & An additional activity occurs \\
\hline Reverse & $\begin{array}{l}\text { Logical opposite of the design } \\
\text { intention occurs }\end{array}$ \\
\hline Other than (other) & $\begin{array}{l}\text { Complete substitution - another } \\
\text { activity takes place or an unusual } \\
\text { activity occurs or uncommon } \\
\text { condition exists }\end{array}$ \\
\hline
\end{tabular}

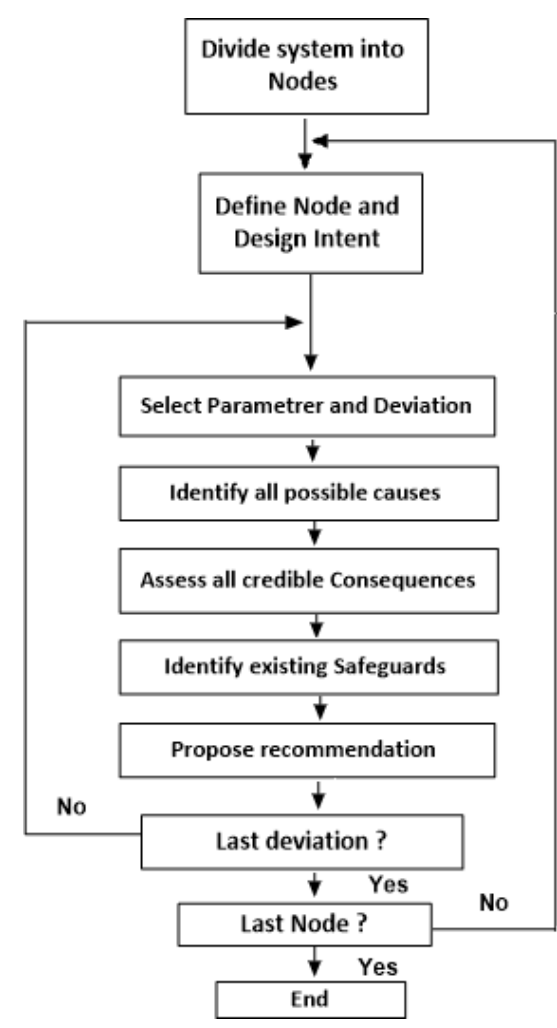

Fig. 2. HAZOP process according to ISO 31.010 (2011). 
Table 3. Identification of deviations leading to risks / hazards.

\begin{tabular}{|c|c|c|c|c|c|c|}
\hline Deviation (parameters/keywords) & More of & Less of & Not & Reverse & More than & Other \\
\hline \multicolumn{7}{|l|}{ Node I } \\
\hline Seed moisture & 'D1 & $\mathrm{D} 2$ & - & - & - & - \\
\hline Drying / Humidification & - & - & D3 & - & - & - \\
\hline Seed granulometry & D4 & D5 & - & - & - & - \\
\hline Seed hardness & D6 & - & & & & \\
\hline Seed cleanness & - & D7 & - & - & - & - \\
\hline \multicolumn{7}{|l|}{ Node II } \\
\hline Press loading & D8 & D9 & & & D10 & - \\
\hline Screw speed & D11 & - & - & - & - & - \\
\hline Heating temperature & D12 & - & - & - & - & - \\
\hline Press pressure: nozzle choice & D13 & D14 & - & - & - & - \\
\hline Preheating the press & - & - & D15 & - & - & - \\
\hline \multicolumn{7}{|l|}{ Node III } \\
\hline Cleaning the press after use & - & - & D16 & - & - & - \\
\hline Oil storage under cold conditions & - & - & D17 & - & - & - \\
\hline $\begin{array}{l}\text { Opacity of the oil storage } \\
\text { bottles }\end{array}$ & - & - & D18 & - & - & - \\
\hline
\end{tabular}

It prevents efficient operation. 
Nova Biotechnol Chim (2021) 20(1): e815

Table 4. Summary table of risk causes associated with deviations.

\begin{tabular}{|c|c|c|c|c|c|c|}
\hline Deviation & D1 & D2 & D3 & D4 & D5 & D6 \\
\hline Cause & $\begin{array}{l}\text { The seeds are stored } \\
\text { in a humid place. }\end{array}$ & $\begin{array}{l}\text { The seeds are } \\
\text { stored in an air- } \\
\text { conditioned and } \\
\text { sunny space. }\end{array}$ & $\begin{array}{l}\text { The seed dryer or } \\
\text { humidifier is not } \\
\text { operative. }\end{array}$ & $\begin{array}{l}\text { The pressed seeds are } \\
\text { very thin or have been } \\
\text { preliminary grinded. }\end{array}$ & $\begin{array}{l}\text { Grinding large seeds is } \\
\text { not done properly to } \\
\text { achieve the desired } \\
\text { particle size. }\end{array}$ & $\begin{array}{l}\text { Seeds that are } \\
\text { intrinsically hard or too } \\
\text { dry (under extreme } \\
\text { conditions of } \\
\text { temperature and } \\
\text { pressure). }\end{array}$ \\
\hline Consequence & $\begin{array}{l}\text { Oil yield loss: } \\
\text { Seeds become } \\
\text { mellow and the oil } \\
\text { is strongly related to } \\
\text { the water. Moisture } \\
\text { content is often the } \\
\text { culprit of a bad } \\
\text { pressing. }\end{array}$ & $\begin{array}{l}\text { Oil yield loss: } \\
\text { The seeds get } \\
\text { harder and the oil } \\
\text { is caught inside } \\
\text { the dried cells. }\end{array}$ & $\begin{array}{l}\text { Oil yield loss: } \\
\text { The pre-drying } \\
\text { considerably } \\
\text { increased the hardness } \\
\text { of seeds. This } \\
\text { automatically generates } \\
\text { an interrupt, blocking } \\
\text { the press head. }\end{array}$ & $\begin{array}{l}\text { Zero yield: } \\
\text { Because of the } \\
\text { fineness of seeds. } \\
\text { Seeds came out } \\
\text { through pores } \\
\text { dedicated to the oil } \\
\text { evacuation. }\end{array}$ & $\begin{array}{l}\text { Productivity loss: } \\
\text { A significant amount of } \\
\text { the oil came out the } \\
\text { cake. }\end{array}$ & $\begin{array}{l}\text { Machine breakdown } \\
\text { and productivity loss: } \\
\text { The screw cannot grind } \\
\text { the seed that remains } \\
\text { caught inside the press. } \\
\text { Congestion did not let } \\
\text { the screw react to } \\
\text { advance the material } \\
\text { even if the revolutions } \\
\text { per minute increased to } \\
\text { high enough values. }\end{array}$ \\
\hline
\end{tabular}


Table 4. Summary table of risk causes associated with deviations. Continued.

\begin{tabular}{|c|c|c|c|c|c|c|}
\hline Deviation & D7 & D8 & D9 & D10 & D11 & D12 \\
\hline Cause & $\begin{array}{l}\text { Seeds are not } \\
\text { washed or contain a } \\
\text { significant amount } \\
\text { of dust }\end{array}$ & $\begin{array}{l}\text { At start-up, the } \\
\text { press is generally } \\
\text { loaded. } \\
\text { A total loading of } \\
\text { press is required } \\
\text { to ensure the } \\
\text { desired pressure. }\end{array}$ & $\begin{array}{l}\text { During steady-state } \\
\text { operation the press is } \\
\text { not loaded globally. }\end{array}$ & $\begin{array}{l}\text { Seeds with other } \\
\text { elements are } \\
\text { introduced (metal } \\
\text { parts, plastics, paper, } \\
\text { etc.) }\end{array}$ & $\begin{array}{l}\text { The revolutions per } \\
\text { minute applied to the } \\
\text { motor speed controller } \\
\text { are high. }\end{array}$ & $\begin{array}{l}\text { The temperature could } \\
\text { increase if the heat is } \\
\text { supplied via the press } \\
\text { heating ring, or if the } \\
\text { pressure inside the } \\
\text { press increases, it } \\
\text { directly increases the } \\
\text { temperature }\end{array}$ \\
\hline Consequence & $\begin{array}{l}\text { Quality loss: } \\
\text { Dust containing } \\
\text { undesirable } \\
\text { elements decreases } \\
\text { the oil quality. }\end{array}$ & $\begin{array}{l}\text { Same } \\
\text { consequence of } \\
\text { D6 }\end{array}$ & $\begin{array}{l}\text { Productivity loss: } \\
\text { There is not enough } \\
\text { pressure inside the } \\
\text { press and a significant } \\
\text { amount of oil in the } \\
\text { outgoing cake. }\end{array}$ & $\begin{array}{l}\text { Machine breakdown } \\
\text { and quality loss: } \\
\text { Hard objects break } \\
\text { the screw and plastic } \\
\text { elements can } \\
\text { significantly damage } \\
\text { the oil } \\
\text { quality. }\end{array}$ & $\begin{array}{l}\text { Machine breakdown } \\
\text { and productivity loss: } \\
\text { Short residence time in } \\
\text { the press involving high } \\
\text { oil content in the cakes } \\
\text { it is also possible to } \\
\text { have overcrowding } \\
\text { between the hopper and } \\
\text { the screw because the } \\
\text { transfer of material is } \\
\text { more important than the } \\
\text { pressing speed. }\end{array}$ & $\begin{array}{l}\text { Quality loss: } \\
\text { The cold pressing seed } \\
\text { should be maintained } \\
\text { at a temperature below } \\
50^{\circ} \mathrm{C}\end{array}$ \\
\hline
\end{tabular}


Nova Biotechnol Chim (2021) 20(1): e815

Table 4. Summary table of risk causes associated with deviations. Continued.

\begin{tabular}{|c|c|c|c|c|c|}
\hline Deviation & D14/D13 & D15 & D16 & D17 & D18 \\
\hline Cause & $\begin{array}{l}\text { The incompatibility } \\
\text { between the nozzle } \\
\text { diameter and the seed } \\
\text { hardness. }\end{array}$ & $\begin{array}{l}\text { Preheating the head press } \\
\text { is not carried out for a } \\
\text { sufficient period and with } \\
\text { the required } \\
\text { temperature. }\end{array}$ & $\begin{array}{l}\text { Postpone the machine } \\
\text { cleaning. }\end{array}$ & $\begin{array}{l}\text { Oil storage at high } \\
\text { temperature. }\end{array}$ & $\begin{array}{l}\text { Oil storage in a } \\
\text { transparent bottle. }\end{array}$ \\
\hline Consequence & $\begin{array}{l}\text { Productivity loss and } \\
\text { operating loss: } \\
\text { If the nozzle is too small, } \\
\text { the seeds at the exit of the } \\
\text { press are retained and the } \\
\text { extraction of the cake } \\
\text { will not be executed, we } \\
\text { notice that the solid seeds } \\
\text { start to come out of the } \\
\text { oil outlet pores. } \\
\text { However, if the nozzle is } \\
\text { too big, there will not be } \\
\text { enough pressure, which } \\
\text { will probably cause an oil } \\
\text { loss in the cake. }\end{array}$ & $\begin{array}{l}\text { Operating loss and Oil } \\
\text { yield loss: } \\
\text { The mechanical gear of } \\
\text { the drive parts at the } \\
\text { press head does not take } \\
\text { place properly and can } \\
\text { easily cause mechanical } \\
\text { stress that will cause a } \\
\text { crack under the applied } \\
\text { force. Moreover, this } \\
\text { quenching will increase } \\
\text { the seed hardness. }\end{array}$ & $\begin{array}{l}\text { Machine breakdown } \\
\text { and operating loss: } \\
\text { cleaning and } \\
\text { maintenance must be } \\
\text { carried out immediately } \\
\text { after pressing because } \\
\text { the delay caused a very } \\
\text { strong bond between the } \\
\text { seeds and the metal of } \\
\text { the press head. Forced } \\
\text { opening probably will } \\
\text { break the press head. }\end{array}$ & $\begin{array}{l}\text { Quality loss: } \\
\text { Some fatty acids are } \\
\text { more fragile than others, } \\
\text { especially unsaturated } \\
\text { fatty acids which have a } \\
\text { high rate of oxidation } \\
\text { under certain conditions } \\
\text { (heat, oxidation catalyst, } \\
\text { etc.) they degrade which } \\
\text { produce a change in the } \\
\text { properties of the } \\
\text { vegetable oil (smell of } \\
\text { rancidity, color change). } \\
\text { This change is toxic for } \\
\text { the organism. }\end{array}$ & $\begin{array}{l}\text { Quality loss: } \\
\text { Many factors accelerate } \\
\text { oxidation: oxygen, light } \\
\text { (UV), contact with pro- } \\
\text { oxidizing metals (iron or } \\
\text { copper), the presence of } \\
\text { pigments such as } \\
\text { chlorophyll, the } \\
\text { presence of enzymes } \\
\text { (lipases ...), and the heat } \\
\text { that will alter the oil } \\
\text { quality and its richness } \\
\text { of the vitamin E. }\end{array}$ \\
\hline
\end{tabular}


Nova Biotechnol Chim (2021) 20(1): e815

Table 5. Corrective measures and nominal values to set up for an adequate cold pressing.

\begin{tabular}{|c|c|c|c|c|c|c|c|}
\hline Deviation & D1/D2 & D3 & D4/D5 & D6 & D7 & D8/D9 & D10 \\
\hline Measure & $\begin{array}{l}\text { Humidity control } \\
\text { (measure the seed } \\
\text { moisture content) } \\
\text { Definition of storage } \\
\text { conditions. }\end{array}$ & $\begin{array}{l}\text { The seeds must be } \\
\text { dried before } \\
\text { pressing. }\end{array}$ & $\begin{array}{l}\text { Sieving to } \\
\text { determine the seed } \\
\text { size, to choose the } \\
\text { right nozzle } \\
\text { diameter. }\end{array}$ & $\begin{array}{l}\text { If the seeds are relatively } \\
\text { hard, it is necessary to } \\
\text { ensure that their moisture } \\
\text { is in the standards ( } 10 \% \\
\text { by weight). } \\
\text { It would be preferable to } \\
\text { work: without heating the } \\
\text { press head, with the } \\
\text { larger } 15 \text { mm diameter } \\
\text { nozzle and with a slow } \\
\text { residence time to avoid } \\
\text { rapid accumulations at } \\
\text { the press crusher barrel. } \\
\text { It would be necessary to } \\
\text { initially introduce a small } \\
\text { amount of seed into the } \\
\text { loading tank and leave } \\
\text { the machine in normal } \\
\text { operation and wait for the } \\
\text { appearance of the first } \\
\text { cake to come out and } \\
\text { then increase the load } \\
\text { gradually to reach a full } \\
\text { load. }\end{array}$ & $\begin{array}{l}\text { Washing the seeds } \\
\text { before use is } \\
\text { essential to remove } \\
\text { undesirable } \\
\text { particles, and it is } \\
\text { always followed } \\
\text { via air blowing, it } \\
\text { makes the pressing } \\
\text { much easier. }\end{array}$ & $\begin{array}{l}\text { Provide a loading } \\
\text { protocol based on } \\
\text { the } \\
\text { recommendations } \\
\text { and measures } \\
\text { presented } \\
\text { previously } \\
\text { (deviation D6). } \\
\text { It is necessary to } \\
\text { completely fill the } \\
\text { seed press to cause } \\
\text { a sufficient } \\
\text { pressure and } \\
\text { consequently to } \\
\text { increase the yield. }\end{array}$ & $\begin{array}{l}\text { Sorting out the raw } \\
\text { material is } \\
\text { necessary to avoid } \\
\text { any undesirable } \\
\text { particles during } \\
\text { loading. }\end{array}$ \\
\hline Nominal Value & $\begin{array}{l}\text { Average seed } \\
\text { moisture content is } \\
\text { an average of the } \\
\text { order of } 10 \% .\end{array}$ & $\begin{array}{l}\text { Seeds humidity } \\
\text { control }\end{array}$ & $\begin{array}{l}\text { The seed size } \\
\text { must be } \\
\text { compatible with } \\
\text { the used nozzle }\end{array}$ & $\begin{array}{l}\text { The water content has a } \\
\text { significant effect on the } \\
\text { seed hardness. However, } \\
\text { using a hardness test } \\
\text { could predict grain } \\
\text { hardness based on } \\
\text { particle size analysis. }\end{array}$ & Towards zero dust & $\begin{array}{l}\text { Fulfilling the press } \\
\text { in a steady state. }\end{array}$ & $\begin{array}{l}\text { Pure raw material } \\
100 \%\end{array}$ \\
\hline
\end{tabular}




\section{Nova Biotechnol Chim (2021) 20(1): e815}

Table 5. Corrective measures and nominal values to set up for an adequate cold pressing. Continued.

\begin{tabular}{|c|c|c|c|c|c|c|c|}
\hline Deviation & D11 & D12 & D13/D14 & D15 & D16 & D17 & D18 \\
\hline Measure & $\begin{array}{l}\text { Reducing the screw } \\
\text { speed increases the } \\
\text { residence time, } \\
\text { ensuring more time } \\
\text { for pressing, thus } \\
\text { increasing the } \\
\text { efficiency of the } \\
\text { extraction. }\end{array}$ & $\begin{array}{l}\text { It is not necessary } \\
\text { to press seeds by } \\
\text { heat in order to } \\
\text { preserve the } \\
\text { maximum of the } \\
\text { antioxidant } \\
\text { elements ensuring } \\
\text { good quality of oil } \\
\text { (the heating } \\
\text { created during the } \\
\text { pressing process } \\
\text { alone could reach } \\
\text { a high } \\
\text { temperature). }\end{array}$ & $\begin{array}{l}\text { Choose the } \\
\text { appropriate nozzle } \\
\text { according to the } \\
\text { seed hardness. }\end{array}$ & $\begin{array}{l}\text { Preheat the press head via } \\
\text { the heating ring for a } \\
\text { period of } 30 \text { min at a } \\
\text { temperature of } 100{ }^{\circ} \mathrm{C} \text {, } \\
\text { and at the same time } \\
\text { rotate the screw at } 30-50 \\
\text { rpm. The rotation of the } \\
\text { screw has a major role in } \\
\text { the mechanics, the } \\
\text { dilation and the } \\
\text { uniformity of the } \\
\text { temperature throughout } \\
\text { the pressing chamber. It } \\
\text { is recommended to } \\
\text { activate the screw } \\
\text { rotation with heat before } \\
\text { the press loading. }\end{array}$ & $\begin{array}{l}\text { Clean the } \\
\text { mechanical parts of } \\
\text { the press head after } \\
\text { use. }\end{array}$ & $\begin{array}{l}\text { Store the oils in a } \\
\text { fresh place and } \\
\text { avoid excess heat. } \\
\text { Preferably a } \\
\text { refrigerator in a } \\
\text { firm bottle to } \\
\text { minimize the } \\
\text { oxidation } \\
\text { phenomenon. }\end{array}$ & $\begin{array}{l}\text { Using an opaque } \\
\text { bottle to avoid } \\
\text { sunlight and } \\
\text { ultraviolet light } \\
\text { that affect the oil } \\
\text { quality. } \\
\text { It is also important } \\
\text { to clean the outer } \\
\text { edges and the } \\
\text { screw thread of the } \\
\text { bottle with a dry } \\
\text { tissue as a } \\
\text { precaution to avoid } \\
\text { the internal } \\
\text { humidity of the } \\
\text { bottle. }\end{array}$ \\
\hline Nominal value & $30 \mathrm{rpm}$ & $\begin{array}{l}\text { Pressing without } \\
\text { temperature or at } \\
\text { lower degree. }(\mathrm{T}< \\
\left.50{ }^{\circ} \mathrm{C}\right)\end{array}$ & $\begin{array}{l}\text { Nozzle diameter } \\
15 \mathrm{~mm} \text { (for } \\
\text { prickly pear seeds) }\end{array}$ & $\begin{array}{l}\text { Preheat the press headfor } \\
30 \text { min at a temperature } \\
\text { around } 100^{\circ} \mathrm{C} \text { and a } \\
\text { press speed } 30-50 \mathrm{rpm} \text {. }\end{array}$ & Immediately. & $\begin{array}{l}\text { Fresh place } \\
\left(\mathrm{T}<20^{\circ} \mathrm{C}\right) .\end{array}$ & $\begin{array}{l}\text { Opaque bottle } \\
\text { with an inner } \\
\text { aluminium wall is } \\
\text { covered with a } \\
\text { cling film which } \\
\text { prevents the direct } \\
\text { contact ofthe oil } \\
\text { with the } \\
\text { metal and avoids } \\
\text { oxidation. }\end{array}$ \\
\hline
\end{tabular}


Besides, the results of the risks identified by the HAZOP analysis are depicted in Table 4, which are more specifically "operability risks" that affect the press performance, the product quality and the economic operation of the unit. Therefore, HAZOP study forms a useful guide to the maintenance personnel, providing measurements recommendation and nominal values listed in Table 5 , to achieve adequate cold pressing.

\section{Results and Discussion}

\section{The optimal conditions of cold pressing method}

The cold-pressing operability risks have been identified based on HAZOP analysis. Each process parameters have been studied in order to determine the optimal pressing conditions. The experience plan has been reduced, according to HAZOP results, instead of performing experiments on all the manipulable variables of the press, the seeds were pressed based on the screw speed variable.

The press performance was more effective and without any operating problems when the pressing is based on the corrective measures and nominal values mentioned below (Table 6 and 7).

Table 6. Raw material storage and feeding press conditions.

\begin{tabular}{lc}
\hline Seed properties & Nominal values \\
\hline Seed moisture & Average of the order of $10 \%$. \\
$\begin{array}{l}\text { Seed hardness } \\
\text { Seed granulometry }\end{array}$ & High hardens level \\
& The grain size must be compatible \\
with the used nozzle, without grinding \\
the seeds.
\end{tabular}

Table 7. Optimal conditions of prickly pear seeds cold pressing.

\begin{tabular}{lll}
\hline Parameters & Nominal value & Corrective measures \\
\hline Screw speed & $30 \mathrm{rpm}$ & $\begin{array}{l}\text { Reducing the speed to } 30 \mathrm{rpm} \text { increases the residence time thus ensuring } \\
\text { more time for the pressing to take place and thus increasing the } \\
\text { extraction efficiency. }\end{array}$
\end{tabular}

Temperature

Press loading

Nozzle diameter

Preheating the press

Cleaning the press after Immediately use press after use

Oil storage under cold Fresh place conditions
Pressing without heat

Total filling of the press $(100 \%)$

$15 \mathrm{~mm}$

Preheat the press head for $30 \mathrm{~min}$ at a temperature around 100 ${ }^{\circ} \mathrm{C}$ and a press speed 30 $-50 \mathrm{rpm}$.

$\left(\mathrm{T}<20^{\circ} \mathrm{C}\right)$
Pressing without heat or at lower temperature $\left(\mathrm{T}<50^{\circ} \mathrm{C}\right)$. The heat created during the pressing process is enough. It is not necessary to press seeds by heat in order to preserve the maximum of the antioxidant elements, ensuring good quality of oil.

Load the seeds with small quantities (wrists of the hand) until the appearance of the first cake $(10-15 \mathrm{~s})$ then completely fill the press. It is necessary to completely fill the seed press to cause a sufficient pressure and consequently to increase the yield.

The grain size must be compatible with the used nozzle.

The rotation of the screw has a major role in the mechanics, the dilation and the uniformity of the temperature throughout the pressing chamber.

It is recommended to activate the screw rotation before the press loading with heat.

Non-cleaning causes a very strong bond between the seeds and the metal of the press head. A forced opening probably will break the press head.

Opaque bottle with an inner aluminium wall is covered with a cling film which prevents the direct contact of the oil with the metal and avoids oxidation.

\section{Oil yield}

The cold-press extraction process was carried out 6 times, without heat changing only the pressing speed and considering HAZOP analysis results mentioned previously. The results obtained in Table 8 show that the highest oil yield is $4.85 \%$ on a dry basis when the pressing is at speed of $30 \mathrm{rpm}$ and the lowest oil yield is $3.13 \%$ when the pressing speed is slower at $15 \mathrm{rpm}$, also the yield decreased to $4.17 \%$ when the 
speed increased above $30 \mathrm{rpm}$. When the screw speed is slower than $30 \mathrm{rpm}$, it provides more time (long residence time) for the seed pressing, but at the same time the press clogs more, which leads to decrease the seeds flow loading and minimize yield. Indeed, when the screw turns faster, more material is moving through the press and this provides less time for the oil to migrate out and be separated from the meal. So, in both cases, a lower yield is obtained. As a result, the optimum pressing speed is $30 \mathrm{rpm}$, at this speed, the press oil extraction rate is higher and a lower amount of oil left in the meal.

Table 8. Variation of oil extracted yield with pressing speed.

\begin{tabular}{ccc}
\hline Test & $\begin{array}{c}\text { Screw speed } \\
{[\mathbf{r p m}]}\end{array}$ & $\begin{array}{c}\text { Oil content } \\
{[\%] \text { dry basis }}\end{array}$ \\
\hline 1 & 15 & 3.13 \\
2 & 20 & 3.78 \\
3 & 25 & 4.07 \\
4 & 30 & 4.85 \\
5 & 35 & 4.57 \\
6 & 40 & 4.17 \\
\hline
\end{tabular}

The obtained cold-pressed seed oil yield $(4.85 \%$, on a dry basis) is lower compared to the seed residual oil content $(7 \%)$ extracted by hexane. Significant amount of oil remains stored in the cake produced during cold pressing.

According to the data, a comparative study (Mouden et al. 2012) that was carried out on Opuntia ficus indica (L.) Mill. seeds (origin from Aït Baamrane), through two different extraction methods, one by cold pressing and the other by solvent, the maximum oil obtained was $(5.90 \%)$ following the cold pressing method and $(7.79 \%)$ following a solvent extraction method. In other studies, as Taoufik et al. (2015) and El Hachimi et al. (2015) results, the seed oil yield of the same studied variety (OFI originate from Ait Baamrane, Morocco) by the same extraction process (solvent extraction) was $(7.6-8.74 \%)$, respectively. The difference between the yield could be attributed to the cultivar, geographical origin of fruits, degree of maturity and the storage conditions but also to the extraction protocols and analytic assays (Brahmi et al. 2020, El Hachimi et al. 2015).

In our case, the cold pressing yield was influenced by seed properties and its storage conditions, press feeding, and operating conditions.

\section{Oil characterisation}

The extracted seed oil has some interesting organoleptic properties, namely a greenish yellow color with a strong characteristic odor. According to Ramadan and Mörsel (2003) study, OFI seed oil contains a lower amount of carotenoids ( $b$-carotene) compared to pulp oil. Carotenoids may be the source of the light-yellow hues of seed oil, while the pulp oil is characterised by dark orange hues.

\section{Fatty acid composition}

The GC results (Table 9) showed that linoleic acid is the dominant fatty acid, with high content that reaches up to $(60.42 \%)$ followed by oleic acid $(21.65$ $\%)$, palmitic acid (12.24\%) and stearic acid (3.88 $\%)$, respectively. Apparently, the extracted oil is highly unsaturated.

Table 9. Fatty acid compositions of prickly pear seed oil.

\begin{tabular}{lc}
\hline Fatty acids & Concentration [\%] \\
\hline Palmitic acid (C16:0) & 12.24 \\
Palmitoleic acid (C16:1 n-7) & 0.70 \\
Margaric acid (C17:0) & 0.05 \\
Heptadecanoic acid (C17:1) & 0.02 \\
Stearic acid (C18:0) & 3.88 \\
Oleic acid (C18:1 n-9) & 21.65 \\
Linoleic acid (C18:2 n-6) & 60.42 \\
$\alpha$-Linolenic acid (C18:3 n-3) & 0.22 \\
Arachidic acid (C20:0) & 0.33 \\
Paullinic acid (C20:1 n-7) & 0.35 \\
SFA : C16:0+C18:0 & 16.12 \\
PUFA: C18: & 60.42 \\
PUFA/SFA: C18:2/ (C16:0+C18:0) & 3.74 \\
\hline
\end{tabular}

SFA = saturated fatty acids; PUFA = polyunsaturated fatty acids; PUFA/SFA = unsaturation ratio.

Our results are in good agreement with Taoufik et al. (2015) results, linoleic acid is the dominant fatty acid $(61.5 \%)$ followed by oleic acid $(21.3 \%)$, palmitic acid $(11.9 \%)$ and stearic acid $(3.3 \%)$, respectively. There is no difference between the fatty acid concentration of our cold-pressed oil and the fatty acid concentration of the solvent extracted oil from the same OFI, and from the same geographical origin (Ait Baamrane, Morocco).

According to Brahmi et al. (2020) results, the Algerian cold-pressed seed oil (OFI) contains 
linoleic acid as the main compound represents $(55,81 \%)$, followed by oleic acid $(12.99 \%)$, palmitic acid $(10.8 \%)$ and stearic acid $(2.97 \%)$, respectively. The cold-pressed seed oil of Brahmi et al. (2020) has a lower concentration of fatty acids compared to our results and Taoufik et al. (2015) results. Therefore, we conclude the extraction method type does not affect the concentration of fatty acids, the geographical origin of the fruit does.

Indeed, Ramadan and Mörsel (2003) explained the difference between the content of fatty acids which is due to different locations of the cactus cultivation, the content of individual fatty acids differed significantly. Also, it is influenced by geographic and climatic differences (El Finti et al. 2013).

\section{Sterols composition}

The sterol fraction of OFI seed oil is defined by betasitosterol as the main component, representing 67.56 $\%$ of the total sterols, followed by campesterol $(11.87 \%)$ and $\Delta 5$-avenasterol $(4.62 \%)$. Other compounds (stigmasterol, $\Delta 7$-avenasterol, cholesterol) were found with a lower percentage (Table 10).

Table 10. Sterol composition of prickly pear seed oil.

\begin{tabular}{lc}
\hline Sterols & Concentration [\%] \\
\hline Cholesterol & 1.03 \\
$\beta$-sitosterol & 67.56 \\
Campesterol & 11.87 \\
$\Delta 5$ - avenasterol & 4.62 \\
$\Delta 7$-avenasterol & 2.72 \\
Stigmasterol & 2.47 \\
\hline
\end{tabular}

The results are in strong alignment with Taoufik et al. (2015), Ramadan and Mörsel (2003). The betasitosterol represented in their studies $75 \%$ and $72 \%$ of total sterols fraction of OFI seed oil, respectively. The contents of $\Delta 5$ - and $\Delta 7$-avenasterols were

higher in cold-pressed oil in comparison with their contents in both solvent extracted oils $(4.8 \%, 3.1 \%$ $0.9 \%, 0.53 \%$, respectively).

Phytosterols, including beta-sitosterol, campesterol, stigmasterol, and others, are known for having many benefits for human health such as lowering of blood cholesterol. For several decades, it has been appreciated the consumption of plant sterols and stanols that lead to favorable shifts in circulating lipid levels (Jones et al. 2000).

\section{Tocopherols composition}

The cold-pressed oil contained the gammatocopherol as the major dominant fat-soluble vitamin representing $97.56 \%$ of total tocopherols. This significant content exceeds the gamma-tocopherol content in the OFI solvent extracted oil (Taoufik et al. 2015), that was $89.1 \%$ from total tocopherols. Regarding the alpha-tocopherol content that represented $1.5 \%$, it was similar. However, betatocopherol was not detected in our oil analysis (Table 11).

Table 11. Tocopherols composition of prickly pear seed oil. (nd - not detected)

\begin{tabular}{lcc}
\hline Tocopherols & {$\left[\mathbf{m g . k g}^{-1}\right]$} & {$[\%]$} \\
\hline Alpha & 12.65 & 1.58 \\
Beta & nd & nd \\
Gama & 777.30 & 97.56 \\
Delta & 6.74 & 0.84 \\
Total tocopherols & 796.70 & $\mathrm{Nd}$ \\
{$\left[\mathrm{mg}_{\mathrm{kg}}{ }^{-1}\right]$} & & \\
\hline
\end{tabular}

According to Ramadan and Mörsel (2003), gammatocopherol was the dominant compound in amount of $330 \mathrm{mg} \cdot \mathrm{kg}^{-1}$, followed by alpha-tocopherol (56 $\left.\mathrm{mg} \cdot \mathrm{kg}^{-1}\right)$. Our experiment revealed that gammatocopherol content was significantly higher (777.30 $\left.\mathrm{mg} \cdot \mathrm{kg}^{-1}\right)$, followed by alpha-tocopherol that represents $\left(12.65 \mathrm{mg} \cdot \mathrm{kg}^{-1}\right)$. Amount of total tocopherols was $796.70 \mathrm{mg} . \mathrm{kg}^{-1}$ that was also much more than referred Ramadan and Mörsel (2003) (403 mg.kg-1 ${ }^{-1}$.

Assessment of prickly pear seed oil yield and quality showed that almost $70 \%$ of high-quality oil has been extracted that contains about double of the total tocopherols in comparison to results of Ramadan and Mörsel (2003). This is due to the methodology followed, which considered the seed properties and its storage conditions, as well as the press feeding and operating conditions. This approach was less devastating and improved the quality of cold-pressed seed oil to $49.4 \%$ compared to results from other studies (Table 12). Pressing without heat enhanced the quality of prickly pears seed oil, preserved its richness in tocopherols sensitive to light (ultraviolet radiation) and heat. In agreement with Bostyn et al. (2008), it was clearly explained that tocopherols 
degradation is due to the major factor which is the temperature, especially above $100{ }^{\circ} \mathrm{C}$. According to Rueda et al. (2016) multivariate factor analysis revealed that tocopherols, particularly the gammatocopherol, was the strongest variable influencing the discrimination of different oils. Furthermore, gamma-tocopherol helps reduce inflammation, guards against certain cancers, and protects against radiation exposure (Gysin et al. 2002; Stone et al. 2004). The gamma-tocopherol, as other tocopherols, also helps moisturize the skin while fighting against wrinkle-forming free radicals (Nagata et al. 2010). Prickly pear oil also contains a high level of antioxidants and has antibacterial properties. Some healthful compounds reduce skin inflammation, as well as prevent skin damage and acne (Koubaa et al. 2017). OFI seed oil is a suitable and safe carrier for delivering other nutrients that cannot be directly applied to the skin, including vitamin A. OFI seed oil has valuable applications in cosmetic applications (AlZahabi et al. 2019). OFI seed oil is highly unsaturated, rich in antioxidants therefore, it could also be added to foods as natural antioxidant additive and fatty acids supplement.

Table 12. Assessment of prickly pear seed oil yield and quality.

\begin{tabular}{lcc}
\hline & Reference & Reference $^{\mathbf{2}}$ \\
\hline Vitamin E concentration [mg.kg-1] & 796.7 & 403 \\
Yield [\%] & 4.85 & 9.8 \\
Oil density [kg.m ${ }^{3}$ ] & & 0.9 \\
Optimization [\%] & & 49.4 \\
\hline
\end{tabular}

${ }^{1}$ Cold-pressed prickly pear seed oil extracted from seeds originated from Aït Baamrane, Morocco

${ }^{2}$ Prickly pear seed oil extracted by solvent, originate from Berlin, Germany (Ramadan and Mörsel 2003).

\section{Acidity}

Observed acidity of OFI seed oil was $0.8 \%$. It is a lower value in relation to the standard value approved by Codex Alimentarius (1999) (6\% for cold-pressed oil) and also in comparison with studies Brahmi et al. 2020 (2.12 \%) and Özcan et al. 2011 $(1.41 \%)$. These high values might be due to the chemical reactions in seeds during oil harvesting, handling or processing. Oil exposed to inappropriate storage conditions deteriorates its quality in different ways, but most often by hydrolysis or oxidation (Kandji 2001). According to the previous data, OFI seed oil is pure and can be considered virgin oil.

\section{Peroxide value}

The PV could be considered an indicator of oils and fats quality and stability (Zahir et al. 2017). The PV of OFI seed oil is 9.6 meq $\mathrm{O}_{2} \cdot \mathrm{kg}^{-1}$ an acceptable peroxide value at the standard value of $15 \mathrm{meq}$ of peroxides. $\mathrm{kg}^{-1}$ of oil for a cold-pressed oil specified by the Codex Alimentarius (1999).

Different cultivars of prickly pear and different extraction methods revealed PV in range from 9.50 to $18.02 \mathrm{meq} \mathrm{O}_{2} \cdot \mathrm{kg}^{-1}$ (South African prickly pear, solvent extracted, DeWit et al. 2017), 12 meq O ${ }^{1}$ (Algerian prickly pear, cold-pressed, Brahmi et al. 2020), and 1.63 meq $\mathrm{O}_{2} \cdot \mathrm{kg}^{-1}$ (Turkish prickly pear, solvent extracted, Özcan et al. 2011). The PV could be affected by the oil oxidation during the extraction and conservation conditions, decreasing of certain antioxidant substances present in oil such as carotenoids, vitamins A and E, and squalenes (Zahir et al. 2017).

\section{Conclusion}

The present study established a risk prevention platform to achieve adequate cold pressing performance for the oil industry. The methodology and correct measurements resulting from the proposed approach could be taken into account for the cold pressing of prickly pear seeds, but also other oilseeds with high hardness of seeds.

The seed oil yield was influenced by properties of seeds, seed storage conditions, press feeding, and operating conditions. Presented methodology had no effect on the fatty acid and sterol contents, but affected oil quality in terms of tocopherols content. Oil had high quality, was rich in essential fatty acids and sterols, very high contents of tocopherols, chemically free from organic solvents, with lower value of acidity and peroxide value. This indicated its purity and stability.

\section{Acknowledgements}

This work would not have been possible without the financial support of CNRST (Morocco) program of excellence scholarships for research. 


\section{Conflicts of Interest}

The authors declare that they have no conflict of interest.

\section{Reference}

Altuntaş E, Y1ldız M (2007) Effect of moisture content on some physical and mechanical properties of faba bean (Vicia faba L.) grains. J. Food. Eng. 78: 174-183.

AlZahabi S, Sakr OS, Ramadan AA (2019) Nanostructured lipid carriers incorporating prickly pear seed oil for the encapsulation of vitamin A. J. Cosmet. Dermatol. 18: 18751884.

Bail S, Stuebiger G, Krist S,Unterweger H, Buchbauer G (2008) Characterization of various grape seed oils by volatile compounds, triacylglycerol composition, total phenols and antioxidant capacity. Food. Chem. 108: 11221132.

Bostyn S, Duvalonen F, Porte C, Coic J, Fauduet H (2008) Kinetic modelling of the degradation of the $\alpha$-tocopherol in biodiesel-rape methyl ester. Bioresour. Technol. 99: 64396445.

Brahmi F, Haddad S, Bouamara K, Yalaoui-Guellal D, ProstCamus E, Pais de Barros J-P, Prost M, Atanasov AG, Madani K, Boulekbache-Makhlouf L, Lizard G (2020) Comparison of chemical composition and biological activities of Algerian seed oils of Pistacia lentiscus L., Opuntia ficus-indica (L.) mill. and Argania spinosa L. skeels. Ind. Crop Prod. 151: 112456.

Chougui N, Tamendjari A, Hamidj W, Hallal S, Barras A, Richard T, Larbat R (2013) Oil composition and characterisation of phenolic compounds of Opuntia ficusindica seeds. Food. Chem. 139: 796-803.

Codex Alimentarius international food standards (1999) Standard for named vegetable oils. CXS 210-1999. http://www.fao.org/fao-who-codexalimentarius/fr/.

De Wit M, Hugo A, Shongwe N (2017) Quality assessment of seed oil from selected cactus pear cultivars (Opuntia ficus indica and Opuntia robusta): Quality assessment of seed oil from $Q$. Ficus-indica and Q. robusta. J. Food. Process. Preserv. 41: 1-8.

El Finti A, El Boullani R, Fallah M, Msanda F, El Mousadik A (2013) Assessment of some agro- technological parameters of cactus pear fruit (Opuntia ficus-indica (L.) Mill) in Morocco cultivars. J. Med. Plant Res. 7: 2574-2583

El Hachimi F, El Antari A, Boujnah M, Bendrisse A, Alfaiz C (2015) Comparison of oils seed and fatty acid content of various Moroccan populations of jujube, grenadier and prickly pear. J.M.E.S. 6: 1488-1502.

Fraczek J, Hebda T, Ślipek Z, Kurpaska S (2005) Effect of seed coat thickness on seed hardnes. Can. Biosyst. Eng. 47: 4.14.5 .

Fuentes-Bargues JL, González-Gaya C, González-Cruz MC, Cabrelles-Ramírez V (2016) Risk assessment of a compound feed process based on HAZOP analysis and linguistic terms. J. Loss Prev. Process Ind.44: 44-52.

Gysin R, Azzi A, Visarius T (2002) $\gamma$-Tocopherol inhibits human cancer cell cycle progression and cell proliferation by down-regulation of cyclins. F.A.S.E.B.J. 16: 1952-1954 ISO 31.010 (2011) Risk Management - Risk Assessment Techniques. International Organization for Standardization. ISO 3960 (1977) Animal and vegetable oils and fats: Determination of peroxide value. International Organization for Standardization.

ISO 659 (1998) Oilseeds: Determination of oil content (Reference method). International Organization for Standardization.

ISO 5508 (1990) Fatty substances of animal and vegetable origin: Analysis by gas chromatography of fatty acid methyl esters. International Organization for Standardization.

ISO 660 (1996) Animal and vegetable fats and oils: Determination of acid value and acidity. International Organization for Standardization.

ISO 6799 (1991) Animal and vegetable fats and oils: Determination of composition of the sterol fraction Method using gas chromatography. International Organization for Standardization.

ISO 9936 (2006) Animal and vegetable fats and oils: Determination of tocopherol and tocotrienol contents by high-performance liquid chromatography. International Organization for Standardization.

Jones PJ, Raeini-Sarjaz M, Ntanios FY, Vanstone CA, Feng JY, Parsons WE (2000) Modulation of plasma lipid levels and cholesterol kinetics by phytosterol versus phytostanol esters. J. Lipid. Res. 41: 697-705.

Kandji N (2001) Etude de la composition chimique et de la qualité d'huiles végétales artisanales consommées au Sénégal. PhD. Thesis, University Cheik Anta Diop (UCAD) de Dakar, Sénégal.

Kletz TA (1999) Hazop and Hazan: Identifying and assessing process industry hazards. $4^{\text {th }} \mathrm{Ed}$. The Institution of Chemical Engineers, 256p.

Koski A, Psomiadou E, Tsimidou M, Hopia A, Kefalas P, Wähälä K, Heinonen M (2002) Oxidative stability and minor constituents of virgin olive oil and cold-pressed rapeseed oil. Eur. Food. Res. Technol. 214:294-298.

Koubaa M, Mhemdi H, Barba FJ, Angelotti A, Bouaziz F, Chaabouni SE, Vorobiev E (2017) Seed oil extraction from red prickly pear using hexane and supercritical $\mathrm{CO}_{2}$ : assessment of phenolic compound composition, antioxidant and antibacterial activities: Opuntia stricta seed oil: extraction and phenolic compounds analysis. J. Sci. Food. Agric. 97: 613-620.

Lacoste F, Lechat H, Paged X, Arnaud JN, Brenne E, Soulet B, Camisuli B, Birot C, Fazeuilth S, Escabasse J (2005) Contrôle des composés indésirables dans les huiles végétales et mise en place d'observatoires origine des contaminants. OCL-Oilseeds and Fats, Crops and Lipids. 12: 372-377.

Laurent P, Roiz J, Wertz J-L, Richel A, Paquot M (2011) Le bioraffinage une alternative prometteuse à la pétrochimie. Biotechnol. Agron. Soc. Environ. 15: 597-610.

Matthäus B, Özcan M (2011) Habitat effects on yield, fatty acid composition and tocopherol contents of prickly pear (Opuntia ficus-indica L.) seed oils. Sci. Hortic. 131: 95-98.

Mouden M, Boujnah M, Mbarki M, Rakib EM, Badoc A, Douira A (2012) Effet de deux méthodes d'extraction et de 


\section{Nova Biotechnol Chim (2021) 20(1): e815}

la période de récolte sur le rendement en huile des graines de figues de barbarie. Bull. Soc. Pharm. Bord. 151: 7-14.

Nagata C, Nakamura K, Wada K, Oba S, Hyashi M, Takeda N, Yasuda K (2010) Association of dietary fat, vegetables and antioxidant micronutrients with skin ageing in Japanese women. Br. J. Nutr. 103: 1493-1498.

Nitièma-Yefanova S, Son G, Yé S, Nébié RHC, BonziCoulibaly Y (2012) Optimisation des paramètres d'extraction à froid de l'huile d'Azadirachta indica A. Juss et effets sur quelques caractéristiques chimiques de l'huile extraite. Biotechnol. Agron. Soc. Environ. 16: 423-428.

Özcan MM, Al Juhaimi FY(2011) Nutritive value and chemical composition of prickly pear seeds (Opuntia ficus-indica L.) growing in Turkey. Int. J. Food. Sci. 62: 533-536.

Rabrenović BB, Dimić EB, Novaković MM, Tešević VV, Basić ZN (2014) The most important bioactive components of cold pressed oil from different pumpkin (Cucurbita pepo L.) seeds. LWT Food Sci. Technol. 55: 521-527.

Ramadan MF, Mörsel J-T (2003) Oil cactus pear (Opuntia ficus-indica L.). Food. Chem. 82: 339-345.

Reniers GLL, Dullaert W, Ale BJM., Soudan K (2005) Developing an external domino prevention framework: Hazwim. J. Loss Prev. Process Ind. 18: 127-138.

Rueda A, Samaniego-Sánchez C, Olalla M, Giménez R, Cabrera-Vique C, Sequer I, Lara L (2016) Combination of analytical and chemometric methods as a useful tool for the characterization of extra virgin argan oil and other edible virgin oils. Role of polyphenols and tocopherols. J. AOAC Int. 99: 489-494.

Schaufler D, Schaufler R (2013) Small-scale oilseed processing guide. PennState University.

Soetaredjo FE, Budijanto GM, Prasetyo RI, Indraswati N (2008) Effects of pre-treatment condition on the yield and quality of Neem oil obtained by mechanical pressing. J. Eng. Appl. 3: 45-49.

Stone WL, Krishnan K, Campbell SE, Qui M, Whaley SG, Yang H (2004) Tocopherols and the treatment of colon cancer. Ann. N. Y. Acad. Sci.1031: 223-233.

Taoufik F, Zine S, El Hadek M, Hassani LMI, Gharby S, Hicham H, Matthäus B (2015) Oil content and main constituents of cactus seed oils Opuntia Ficus-indica of different origin in Morocco. Med. J. Nutrition. Metab. 8: 8592.

Van Hoed V, Ben Ali C, Slah M, Verhé R (2010) Quality differences between prepressed and solvent extracted rapeseed oil. Eur. J. Lipid. Sci. Technol. 112: 1241- 1247.

Zahir E, Saeed R, Hameed MA, Yousuf A (2017) Study of physicochemical properties of edible oil and evaluation of frying oil quality by Fourier Transform-Infrared (FT-IR) Spectroscopy. Arab. J. Chem. 10: S3870-S3876. 